\title{
Social-ecological factors influencing tourist satisfaction in three ecotourism lodges in the southeastern Peruvian Amazon
}

Claudia Torres-Sovero ${ }^{\text {a,b }}$, José A. González ${ }^{\text {b,*, }}$, Berta Martín-López ${ }^{\text {b }}$, Christopher A. Kirkby ${ }^{\text {a }}$

a Asociación Fauna Forever, Calle Alfa Centauro 288, Surquillo, Lima, Peru.

${ }^{\mathrm{b}}$ Social-ecological Systems Laboratory, Department of Ecology, Universidad Autónoma de Madrid, 28049-Madrid, Spain.

*Corresponding author: Tel. +(34) 914978913; Fax. + (34) 914978001; E-mail address: jose.gonzalez@uam.es; Postal address: Departamento de Ecología, Facultad de Ciencias, Universidad Autónoma de Madrid, Campus Cantoblanco, 28049-Madrid, España

\section{Acknowledgements}

We would like to thank INRENA for the research permission $n^{\circ} 009-2009$; as well as Kurt Holle, María La Cruz, María Luisa Gutiérrez, Yohanna Pérez, and all the staff and guides from Rainforest Expeditions. Special thanks to all the tourists who kindly participated in the research and responded to questionnaires. We also thank two anonymous reviewers whose comments have greatly improved the final manuscript. Finally, we are grateful to Huw Lloyd and David Segurado for their help and support during the research. 
- We analyse social-ecological factors that influence visitor satisfaction.

- Three typologies of tourists were found based on socio-cultural factors.

- The quality of the lodge has the largest influence on overall satisfaction.

- Ecological features positively influence satisfaction of only one type of tourist.

- Selective marketing focused on true ecotourists can be used to improve sustainability. 


\section{ABSTRACT}

Analysing the factors that influence visitor satisfaction is critical for the proper management of tourism, particularly in nature tourism enterprises, which are expected to contribute to biodiversity conservation and the development of local people. In this paper, we investigate the relationship between different socio-economic and ecological variables, as well as tourist-operation related factors, on the overall satisfaction of tourists visiting three Amazonian lodges in Peru. We found three typologies of tourists, differing by several socio-economic and cultural factors, and by their motivations. The quality of the lodge was the factor that had the largest influence on overall satisfaction. Only one type of tourist ("true ecotourists") showed a positive relation between their overall satisfaction and ecological features such as the species observed or cultural features such as operation of the lodge by native communities using local guides. Implications for management are discussed in terms of the potential of nature tourism to contribute to sustainable development in the Peruvian Amazon.

Keywords: Peruvian Amazon; Ecotourism; Lodge; Tambopata National Reserve; Tourist satisfaction 


\section{Introduction}

Ecotourism represents a small but growing proportion of the world's tourism (Schulte, 2003; TIES, 2006). Given its close relation to nature, ecotourism has the potential to become an important ally of conservation and to contribute to the long-term preservation of Natural Protected Areas (NPAs) and their biodiversity. Moreover, due to their close link with local people, ecotourism enterprises that incorporate a social dimension may become powerful tools for local development. In this way, ecotourism may fight poverty and rural exclusion in NPAs and their surroundings (Alcorn, 1993; Gössling, 1999; Krüger, 2005; Stronza, 2000).

In Latin America, ecotourism is emerging as a new market with substantial development potential due to its biological and cultural diversity (Coppin, 1992; PNUMA, 2003). Currently, ecotourism growth rates exceed those of traditional tourism (Schulte, 2003), particularly in countries such as Belize, Costa Rica, and, more recently, Peru. For example, the number of visitors to NPAs in Peru increased by $250 \%$ between 1990 and 1999 (Schulte, 2003). Taking this growth into account, an increasing number of conservationists consider ecotourism a strategic tool to strengthen nature conservation programs and a major source of economic activity that might contribute to local rural development (Lindberg, 1991; Okello et al., 2001; Okello \& D’amour, 2008; Stronza, 2000; Stronza \& Pêgas, 2008; Tobias \& Mendelsohn, 1991; Wunder, 2000).

Peru receives approximately 800000 tourists per year. Most of these tourists are attracted by Peru's cultural and archaeological richness and its large biological diversity, 
which constitute the country's main attraction for international ecotourists (MINCETUR, 2009). Covering $13.9 \%$ of the national territory, Peru currently has 61 NPAs, 13 of which generate income from ecotourism developments (Chávez, 2005). Official statistics show that 7 out of every 10 tourists who visit the country travel to at least one NPA. Macchu Picchu Sanctuary, Manu National Park, Paracas National Reserve, and Tambopata National Reserve are the most visited NPAs, collecting $95 \%$ of the national revenue from ecotourism (Chávez, 2005; MINCETUR, 2009). The National Institute for Natural Resources (INRENA) is the governmental institution that is in charge of NPAs and establishes the rules and regulations that affect ecotourism development in these areas. Native communities living inside Communal Reserves can manage these areas with the State through the establishment of co-management contracts.

To maximise the potential of ecotourism as a useful tool for nature conservation and local development, it is critical to know the major social and ecological factors that influence ecotourist satisfaction. This aspect has been widely analysed in relation to wildlife in Africa (Akama \& Mukethe-Kieti, 2003; Lindsey et al., 2007; Okello et al., 2001; Williams et al., 2000), Asia (Hasegawa, 2010), and Europe (Oliveira \& Pereira, 2008).

Devesa et al. (2010) have analysed the relationships between tourist satisfaction and motivation for travel. However, as far as we know, no such studies have been conducted in the Peruvian Amazon.

In the current study, we aim to: (a) characterise the typology of tourists visiting the Tambopata National Reserve (Madre de Dios, Perú), and (b) determine the main social and ecological variables that influence tourist satisfaction. We believe this research will have a 
clear practical application in improving ecotourism planning and will strengthen the role of ecotourism in rural development and conservation in the Amazon region.

\section{Study area}

The research was conducted at Tambopata National Reserve (TNR) and its surroundings, a tropical rainforest area of high natural and cultural value (Erwin, 1984;

Gentry \& Terborgh, 1990; Foster et al., 1994; Yu et al., 1997). TNR is located on the south part of the Tambopata River in the Department of Madre de Dios, southeastern Peru ( $9^{\circ} 57^{\prime}$ $13^{\circ} 20^{\prime} \mathrm{S}, 68^{\circ} 39^{\prime}-72^{\circ} 31^{\prime} \mathrm{O}$ ). The TNR comprises 274690 hectares (see Fig. 1) and is bounded by Bolivia on the west side, by the Bahuaja-Sonene National Park on the south and by the Kotsimba Native Community on the east. The buffer zone of the TNR extends from the Kotsimba Native Community to the Heath River. The Infierno Native Community is located adjacent to the TNR.

Ecotourism at TNR began in 1976 with the building of two lodges located along the Tambopata and Madre de Dios rivers. The ecotourism industry grew during the 1990's, mainly due to the increasing economic stability of the country and the decrease in terrorism, which had severely limited tourism development during the 1980's. The establishment of the Tambopata-Candamo Reserved Zone and the scientific research conducted in this area helped to highlight its international relevance (Kirkby et al., 2000; Kirkby, 2002; Yu et al., 1997). Only three ecotourism lodges existed in the area in 1989, 
and the number of lodges increased to 24 in 2002, with a parallel increase in the number of ecotourists visiting the area (from 3000 to 18 000; Kirkby, 2002).

Our research was conducted in three tourist lodges located along the Tambopata River (Fig. 1) and operated by Rainforest Expeditions (RF), a Peruvian company founded in 1992. The three lodges have similar standards but marked differences in their location, years of operation, and management arrangement with local communities:

(a) Posada Amazonas lodge is located inside the territory of the native community of Infierno, surrounded by a protected area that covers 3000 hectares. Posada Amazonas is a joint venture ecotourism project between RF and the native community. The partners signed a 20-years contract in 1996 agreeing to split profits, $40 \%$ to RF and $60 \%$ to the native community. RF is in charge of the logistics and the native community of Infierno owns the lodge and contributes their knowledge of the area. This lodge has operated since 1998. The forest around the lodge is managed and preserved by the community members, and hunting and logging are forbidden. It is a well-preserved secondary rainforest containing large trees and endangered and charismatic wildlife species that can still be observed. This lodge received 6613 tourists in 2009.

(b) Refugio Amazonas is a relatively new lodge, operating since 2005. It is located inside the TNR, adjacent to a Brazilian nut concession. The secondary rainforest that surrounds the lodge has large trees, but has been subjected to intense logging and hunting pressure by members of the neighbouring community of Baltimore. The lodge received 4024 tourists in 2009. 
(c) Tambopata Research Center was the first lodge established in the area by RF. It was created as a Biological Station with the purpose of studying the macaw clay lick. It is located inside the TNR, adjacent to the Bahuaja-Sonene National Park (see Fig. 1). The lodge is surrounded by well-preserved primary rainforest, mainly because it is located near a strictly protected National Park and is difficult to access. The lodge has been operated by RF since 1992 and received 1492 tourists in 2009.

\section{Methodology}

\subsection{Data collection}

Data were collected during June, July and August 2009 in the three ecotourism lodges studied. In each activity/trail, a researcher accompanied the ecotourist group. The researcher recorded ecological data such as the species and number of individuals observed for charismatic mammals (primates, ungulates, giant river otter, and cats), birds (psittacids and representative birds), herpetofauna (frogs, caimans, and snakes), entomofauna (large insects and tarantulas), distinguishing between those observed within $25 \mathrm{~m}$ of the trail from those observed further away. The researcher also recorded the weather conditions prevailing during the activity, the different types of forest present (ecological succession state and conservation status), the total duration of the activity, and the length of the trail in kilometres.

Once the activity was completed, the researcher administered a questionnaire to all individual ecotourists of the group. The questionnaire consisted of 11 questions (see 
Appendix 1) including nationality, profession, age, main motivation for the visit, income, education level, number of companions, membership of a NGO, previous visits to NPAs, previous visits to tropical forests, how they rated the quality of the lodge and its logistics, and their overall satisfaction with the recent activity/trail. A total of 320 questionnaires were collected in the three lodges: 39\% in Posada Amazonas, 35\% in Refugio Amazonas, and 26\% in Tambopata Research Center. Later, RF provided us with information about the place of origin of the naturalist guide and their valuation of the quality of the guide (based on questionnaires conducted by the enterprise).

\subsection{Data analysis}

First, to identify and characterise the tourists' typology we used a hierarchical cluster analysis, employing the Bray-Curtis distance and Ward's method. The variables used to identify the typology of tourists included socio-economic aspects (i.e., country of origin, profession, age, education level, and income) and environmental and visit attitudes (i.e., whether the tourist was a member of an environmental organisation, the number of NPAs they had visited, previous visits to other tropical forests, the main motivation of the visit, and the number of companions) (Table 1). To characterise each type of tourist obtained in the hierarchical cluster analysis, we used contingency tables $\left(\chi^{2}\right.$ test).

Second, to explore which factors influenced the overall satisfaction of visitors during their activity, we used non-parametric statistics (Mann-Whitney and Kruskal-Wallis tests). When the Kruskal-Wallis test achieved 90\% significance, we used Bonferroni's multiple comparison post-test to compare the overall satisfaction of one group with another. To test 
the effect of continuous variables on visitors' overall satisfaction, we also used Spearman correlation analyses. The variables used in these analyses were related to ecological aspects and the specific characteristics of the visit, and to the guide and lodging (Table 1).

Finally, we analysed the joint effect of the ecological variables, guide and lodgingrelated variables (see Table 1), and visitors' typology (obtained in the hierarchical clusters analysis), on the overall satisfaction using stepwise multiple regression. The best model was selected based on a comparison of the adjusted $\mathrm{R}^{2}$ of various models that consisted of different subsets of the independent variables. A Principal Component Analysis of variables was previously carried out to avoid collinearity in the regression analysis. We selected those factors with eigenvalues $>1$ (Kaiser criterion) as explicative factors in the multivariate regression analysis.

Logarithmic transformation of the continuous variables was necessary to avoid heteroscedasticity in these analyses. We defined significance at the level $p \leq 0.1$, as our results were focused on conservation management decisions (Field et al., 2004, 2005).

\section{Results}

\subsection{Identification and characterisation of tourist types}

At the highest coefficient of dissimilarity, two different clusters were found: the first cluster is represented by older visitors who have the highest income, and the second cluster is represented by younger tourists. At the significance level of 0.05 , we identified three 
main tourist typologies (Fig. 2), with significant differences in variables such as age ( $\chi^{2}=$ 466.2, $\mathrm{p}<0.001)$, education level $\left(\chi^{2}=63.7, \mathrm{p}<0.001\right)$, income $\left(\chi^{2}=134.3, \mathrm{p}<0.001\right)$, and the major motivations for visiting the area $\left(\chi^{2}=32.8, \mathrm{p}<0.001\right)$ (Fig. 3). We did not find association between the type of tourist and lodge (Contingency table analysis, $\chi^{2}=4.9$, $\mathrm{p}=0.29)$ (Fig. 4).

Type A tourists were characterised as older than 41 years (mean= 51), having a high income (>50 000 US\$/year), postgraduate education (36.4\%) and involved in the business (18.8\%) and education sectors (23.4\%). The main travel motivation of these tourists was to have an experience in the wild (37.7\%). Only a quarter of these tourists belonged to an environmental NGO, and a large majority of them had previously visited NPAs and tropical forests.

Type B tourists were characterised as between 21-40 years old (mean=30), having a high income, postgraduate education (44.3\%), and involved in the business (27.8\%) or education (24.8\%) sectors. Their main travel motivation was seeking an experience (32.2\%), and most of them had visited NPAs and tropical rainforests prior to this trip.

Type $\mathrm{C}$ tourists were characterised as younger than 21 years old (mean=18), having a low income ( $<20000$ US\$year) and not having finished their university studies $(66.7 \%)$. Their major travel motivation was seeking adventure (35.7\%). Only 10\% belonged to an environmental NGO. Half of these tourists had previously visited a NPA, but only $23 \%$ had visited a tropical rainforest.

\subsection{Variables influencing the level of satisfaction in each tourist type}


The overall satisfaction level of Type A tourists was positively correlated with lodge quality. Satisfaction level was higher in lodges that were not managed by a native community. The origin of the naturalist guide and his/her quality did not have an influence on tourist satisfaction level (Table 2). The satisfaction level of this tourist type was significantly higher in trails of intermediate distances, between 2 and $4 \mathrm{~km}$ long. Terrestrial activities were positively associated with higher satisfaction levels, but cultural activities showed lower satisfaction levels (Table 2). Type A tourists also showed significantly higher satisfaction levels with activities conducted in primary and pioneer rainforests and lower satisfaction levels with activities conducted in human-transformed forests under agroforestry uses.

Type B tourists showed a positive correlation between overall satisfaction and the quality of the lodge (Table 2). They also showed a higher level of satisfaction with activities guided by a native guide. This type of tourists showed higher satisfaction levels with terrestrial activities and with activities conducted in primary and pioneer rainforest. Lesser satisfaction levels were associated with nocturnal activities. Type B tourists were the only individuals whose satisfaction was significantly related to the observation of charismatic wildlife during the activity. In this sense, their overall satisfaction was positively correlated with the number of mammal and bird species observed along the trail (Table 2).

Similar to the first two tourist typologies, Type C tourists' satisfaction was positively related with the quality of the lodges. However, whether the lodge was managed by a native 
community or not did not influence the satisfaction of Type $C$ tourists (Table 2). Regarding the characteristics of the activity, their satisfaction level was not influenced by the number of hours or the distance walked, but showed a significant correlation with weather conditions while on the trail. Type $\mathrm{C}$ tourists also showed a significant preference for the activity called collpa (clay lick), consisting of the observation of psittacids eating clay on a clay bank. In contrast to the other two typologies, Type $\mathrm{C}$ tourists showed a lower satisfaction level with terrestrial activities. There was no significant relation between their overall satisfaction and the forest conservation status or successional state, or the observation of charismatic wildlife species (Table 2).

\subsection{Factors influencing the tourists' overall satisfaction}

A three-factor solution that explained $61.5 \%$ of the variance was selected as an adequate explanation of the data (Table 3). Factor 1 (28.5\%) was associated with the specific characteristics of the tourist activity, such as the distance covered by tourists during the activity and aquatic activities (both variables exhibited positive scores), the duration of the activity, and the size of the group in the activity (which exhibited negative scores). Factor $2(17.5 \%)$ captured aspects related to the logistics of tourism activity. While positive factor scores reflected the quality of nature guides and terrestrial activities, negative scores were related to the management of lodge by a native community. Factor $3(14.5 \%)$ captured the quality of the lodge. 
Finally, in the best model obtained, overall satisfaction was explained by Factor 1, Factor 2, Factor 3, and the tourists of Type A and Type B (see Table 4). All variables had a significantly positive effect on the tourists' overall satisfaction. Whereas the logistics and quality of the lodge (Factor 3) had a strong influence on tourists' overall satisfaction, the aquatic and terrestrial activities with long routes and in small groups of visitors (Factors 1 and 2) had less influence. The quality of the nature guides positively influenced satisfaction, but the management by a native community had a negative effect (see Factor 2). Finally, Type B tourists showed a higher level of satisfaction (Table 4).

\section{Discussion}

Measuring the level of satisfaction of ecotourists is important as it can serve as a barometer of the "quality" of the service offered and it is a useful tool for designing more efficient conservation and management plans (Foster, 1999; Haber \& Lerner, 1998). Our results provide new insights on the social and ecological variables that have a stronger influence on ecotourists' overall satisfaction in the Peruvian Amazon. Most of the tourists visiting the lodges located in the TNR showed a relatively high satisfaction with the activities conducted, but the satisfaction level was highly influenced by the typology and characteristics of the tourists, and by a set of ecological and socio-economic variables that interact in a complex manner.

Three clear and differentiated tourist typologies were identified in the lodges of TNR. Type A grouped older persons with high income and education levels who were primarily 
looking for an experience in the wild. This tourist type typically showed a higher level of service requirements, demanding attention and comfort. A second type (Type B) consisted of middle-age persons with high incomes and university level education, who showed greater interest in biodiversity and local cultures. We named them as "true ecotourists" because they were the only ones whose satisfaction was positively correlated with the observation of charismatic wildlife, endangered birds and mammals, and cultural aspects (such as lodge management by a native community, or the presence of native guides). Finally, Type C grouped tourists with low incomes and young-adventurer profiles, whose main motivations and interests were quite different from those of the other tourist types. Motivation has been identified as one of the factors that best characterises tourist's typologies and greatly influences their expectations and overall satisfaction (Devesa et al., 2010).

One of the main features that attract ecotourists to remote NPAs is the possibility of observing singular species, particularly large terrestrial mammals or megafauna (Naidoo \& Adamowicz, 2005; Okello et al., 2001; Okello et al., 2008; Walpole \& Leader-Williams, 2002). The most renowned mammal species in the ecotourism market are typically flagship species found in Africa that, because of their large size, can be easily observed (Krüger, 2005). This constitutes a large advantage over Latin American tropical rainforests, where species are smaller, more evasive, and access to them is more difficult (Groom et al., 1991). Additionally, communication about endangered species from the Amazon remains scarce. For example, species such as the giant river otter are poorly known by most tourists, despite its size and the plentiful opportunities to observe it in oxbow lakes (Steib \& Schenk, 1994). 
The fame of the Tambopata and Manu regions, in the Department of Madre de Dios, is mostly due to the presence of large collpas. On the clay banks, very early in the morning, several species of psittacids feed on clay for physiological and dietary reasons, among others (Brightsmith \& Aramburú, 2004; Gilardi et al., 1999; Munn, 1998). The presence of large collpas facilitates the observation of psittacids, mainly large macaws of the genus Ara that capture greater tourist attention. This explains why they are used as keystone species in the Amazon ecotourism market. In addition, these birds are not only important flagship species for biodiversity conservation fund-raising (Kerley et al., 2003; Walpole \& LeaderWilliams, 2002), but also for generating important economical benefits for local people inhabiting NPAs or their surroundings (Groom et al., 1991; Munn, 1998). However, it should be highlighted that only Type $\mathrm{C}$ tourists showed a higher satisfaction level with the collpa activity, although Type B tourists showed a clear correlation between their satisfaction level and the number of charismatic birds observed during the activity.

Our results show that lodge characteristics is the main variable that influenced the tourists' satisfaction level, and was far more important than the other ecological or sociocultural variables analysed. Logistics in a tropical rainforest involve challenges that are mostly related to the difficulties of operating in remote places with difficult access. However, ecotourists typically demand certain lodge quality criteria, despite the fact that lodges are not expected to be more important than nature and culture in the ecotourism market (Ceballos-Lascuráin, 1996). Several studies show that the characteristics of the lodge do not and should not influence the "true ecotourist" satisfaction level (Mackoy \& Osland, 2004; Ceballos-Lascuráin, 2008). Contrarily, our results indicate that this factor 
significantly influenced the satisfaction level of all three different tourist typologies identified in the lodges studied in TNR.

The quality of the naturalist guide appears to be another key factor for tourist satisfaction (Bowen, 1999). Good guides are appreciated not only for their knowledge of nature and culture and their ability to identify fauna and flora (Mackoy \& Osland, 2004), but also for their capacity to solve logistical problems and fulfil tourists' expectations (Geva \& Goldman, 1989). In this study, the multivariate regression showed that the guide's quality influenced the tourists' satisfaction level. Given these results, a continued training program for naturalist guides of TNR appears critical for improving the experience of tourists. This is particularly true for native guides, who are more integrated in ecotourism projects and should be provided the opportunity to transmit their wide knowledge and experience in a more efficient way.

Management by a native community was negatively related with satisfaction level (with the only exception of Type B tourists), likely reflecting the need for greater training and qualification of native people involved with the ecotourism market. Management of a jungle lodge by not specialized personnel is not an easy task. The agreement between RF and the native community of Infierno implies a continuous training program for native people in the different tasks required for tourism operation. However, the staff works in rotational shifts and during short periods of time, so that every member of the community has the same opportunities. This implies that there is frequently new staff, increasing the likelihood that mistakes occur that negatively affect satisfaction of the more demanding tourists. 


\section{Conclusions}

Ecotourism has great potential as a tool to promote conservation in the TNR while benefiting local people who reside in the area. However, ecotourism will not be a panacea for solving the many problems of the region. To increase the efficiency of the ecotourism industry as a sustainable development tool, it will be necessary to improve the planning and management of tourist activities, bearing in mind the various existing tourist typologies when designing tourist products.

Selective target marketing represents a feasible complement to current management practices which focus on tourists who may not necessarily be interested in protecting the local environment or promoting local development (Dolnicar \& Leish, 2008). In this sense, selective marketing focused on "true ecotourists" should be maximised in the Peruvian Amazon, as this typology of tourist usually generates a greater aggregated value from a social and environmental sustainability viewpoint.

Joint-ventures between local native communities and specialised tourism companies are likely to be a promising option for ecotourism in the Peruvian Amazon. However, our results show that management by native communities entails some difficulties and can only succeed if there is a solid and continuous training program for local people, particularly for native guides. Given these conditions, joint-venture tourism lodges could become a useful strategy for the conservation of biodiversity and the promotion of human well-being in local communities. 


\section{References}

Akama, J., \& Mukethe-Kieti, D. (2003). Measuring tourist satisfaction with Kenya's wildlife safari: a case study of Tsavo West National Park. Tourism Management, 24, 73-81.

Alcorn, J. (1993). Indigenous peoples and conservation. Conservation Biology, 7, 424-426.

Bowen, D. (1999). Antecedents of consumer satisfaction and dis-satisfaction (CS/D) on long-haul inclusive tours - a reality check on theoretical considerations. Tourism Management, 22, 49-61.

Brightsmith, D., \& Aramburú, R. (2004). Avian geogaphy and soil characteristics in southeastern Peru. Biotropica, 36, 534-543.

Ceballos-Lascuráin, H. (1996). Tourism, ecotourism and protected areas: the state of nature-based tourism around the world and guidelines for its development. Gland, Switzerland: IUCN.

Ceballos-Lascuráin, H. (2008). Ecotourism and ecolodge development in the $21^{\text {st }}$ century. In A. Stronza, \& W. H. Durham, Ecotourism and Conservation in the Americas (pp. 193-206). Wallingford, Oxfordshire: CABI Publishing.

Chávez, J. M. (2005). Coordinación de políticas públicas para el desarrollo sostenible del sector turismo en el Perú. Lima: Naciones Unidas, CEPAL.

Coppin. L. (1992). Ecoturismo y América Latina: una aproximación al tema. Estudios y Perspectivas en Turismo, 1, 7-14. 
Devesa, M., Laguna, M., \& Palacios, A. (2010). The role of motivation in visitor satisfaction: empirical evidence in rural tourism. Tourism Management, 31, 547552.

Dolnicar, S., \& Leisch, F. (2008). Selective marketing for environmentally sustainable tourism. Tourism Management, 29, 678-680.

Erwin, T. L. (1984). Tambopata Reserve Zone, Madre de Dios, Peru: history and description of the reserve. Revista Peruana de Entomología, 27, 1-8.

Field, S. A., Tyre, A. J., Jonzén, N., Rhodes, J. R., \& Possingham, H. P. (2004). Minimizing the cost of environmental management decision by optimizing statistical thresholds. Ecology Letters, 7, 667-675.

Field, S. A., Tyre, A. J., \& Possingham, H. P. (2005). Optimizing allocation of monitoring effort under economic and observational constraints. Journal of Wildlife Management, 69, 473-482.

Foster, D. (1999). Measuring customer satisfaction in the tourism industry. Third International and Sixth National Research Conference on Quality Management. The Centre for Management Quality Research at RMIT University, Melbourne.

Foster, R. B., Parker III, T. A., Gentry, A. H., Emmons, L. H., Chicchon, A., Schulenberg, T., Rodriguez, L., Lamas, G., Ortega, H., Icochea, J., Wust, W., Rono, M., Castillo, J. A., Phillips,O. L., Reynel, C., Kratter, A., Donahue, P. K., \& Barkley, L. J. (1994). The Tambopata-Candamo Reserve Zone of south-eastern Peru: a biological assessment. RAP working papers 6. Washington, DC: Conservation International. 
Gentry, A. H., \& Terborgh, J. 1990. Composition and dynamics of the Cocha Cashu "mature" floodplain forest. In A. H. Gentry (Ed.), Four neotropical rainforests (pp. 542-564). New Haven: Yale University Press.

Gilardi, J. D., Duffery, S. S., Munn, C. A., \& Tell, L. A. (1999). Biochemical functions of geophagy in parrots: detoxification on dietary toxins and cytoprotective effects. Journal of Chemical Ecology, 25, 897-922.

Gössling, S. (1999). Ecotourism: a means to safeguard biodiversity and ecosystem functions? Ecological Economics, 29, 303-320.

Groom, M. J., Podolsky. R. D., \& Munn, C. A. (1991). Tourism as a sustained use of wildlife: a case study of Madre de Dios, Southeastern Peru. In J. G. Robinson, \& K. H. Redford (Eds.), Neotropical wildlife use and conservation (pp. 393-412). Chicago: University of Chicago Press.

Haber, S., \& Lerner, M. (1998). Correlates of tourist satisfaction. Annals of Tourism Research, 25, 197-201.

Hasegawa, H. (2010). Analyzing tourist's satisfaction: A multivariate ordered probit approach. Tourism Management, 31, 86-97.

Kerley, G. I. H., Geach, B. G. S., \& Vial, C. (2003). Jumbos or bust: do tourist's perceptions lead to an under-appreciation of biodiversity? South African Journal of Wildlife Research, 33, 13-21.

Kirkby, C.A. (2002). Estándares ecoturísticos para la Reserva Nacional Tambopata, el Parque Nacional Bahuaja Sonene, y sus Zonas de Amortiguamiento, Madre de Dios, Perú. Lima: WWF-OPP. 
Kirkby, C.A., Doan, T. M., Lloyd, H., Farfan, A. C., Arriaga, W. A., \& Marin, A. P. (2000). Tourism development and the status of neotropical lowland wildlife in Tambopata, south-eastern Peru: Recommendations for tourism and conservation. London: Tambopata Reserve Society (TReeS).

Krüger, O. (2005). The role of ecotourism in conservation: panacea or Pandora's box. Biodiversity and Conservation, 14, 579-600.

Lindberg, K. (1991). Policies for maximizing nature tourism's ecological and economic benefits. USA: World Resources Institute.

Lindsey, P. A., Alexander, R., Mills, M. G. L., Romañach, S., \& Woodroffe, R. (2007). Wildlife viewing preferences of visitors to protected areas in South Africa: Implications for the role of ecotourism in conservation. Journal of Ecotourism, 6, 19-33.

Mackoy, R. D., \& Osland, G. E. (2004). Lodge selection and satisfaction: attributes valued by ecotourists. The Journal of Tourism Studies, 15, 13-25.

MINCETUR (Ministerio de Comercio Exterior y Turismo del Perú). 2009. Turismo estadísticas y publicaciones. Available from http://www.mincetur.gob.pe/newweb/Default.aspx?tabid=3459.

Munn, C. (1998). Adding value to nature through macaw-orientated ecotourism. Journal of the American Veterinary Medical Association, 212, 1246-1249.

Naidoo, R., \& Adamowicz, W. (2005). Biodiversity and nature-based tourism at forest reserves in Uganda. Environmental and Development Economics, 10, 159-178. 
Okello, M. M., Wishitemi, B. E. L., \& Mwinzi, A. M. (2001). Relative importance of conservation areas in Kenya based on diverse tourist attractions. The Journal of Tourism Studies, 12, 39-49.

Okello, M. M., Manka, S. G., \& D’Amour, D. E. (2008). The relative importance of large mammal species for tourism in Ambroseli National Park, Kenya. Tourism Management, 29, 751-760.

Oliveira, P., \& Pereira, P. T. (2008). Who values what in a tourism destination? The case of Madeira island. Tourism Economics, 14, 155-168.

PNUMA. 2003. GEO América Latina y el Caribe. Perspectivas del Medio Ambiente. Programa de las Naciones Unidas para el Medio Ambiente, Oficina Regional para América Latina y el Caribe (ORPALC) y División de Evaluación y Alerta Temprana (DEAT). Available from http://www.onu.org.cu/uunn/sistemas/geo4_2.pdf

Schulte, S. (2003). Guía conceptual y metodológica para el desarrollo y planificación del sector turismo. Santiago de Chile: Naciones Unidas.

Steib, E., \& Schenk, C. (1994). Giant Otters and ecotourism in Peru. IUCN Otter Specialist Group Bulletin 9, 7-8.

Stronza, A. (2000). Because it is ours: community-based ecotourism in the Peruvian Amazon. Ph.D. dissertation, University of Florida, Gainesville.

Stronza, A., \& Pêgas, F. (2008). Ecotourism and conservation: two cases from Brazil and Peru. Human Dimensions of Wildlife, 13, 263-279.

TIES (2006). The International Ecotourism Society. TIES Global Ecotourism. Available from http://www.ecotourism.org 
Tobias, D., \& Mendelsohn, R. (1991). Valuing Ecotourism in a Tropical Rain-Forest Reserve. Ambio, 20, 91-93.

Walpole, M. J., \& Leader-Williams, N. (2002). Tourism and flagship species in conservation. Biodiversity Conservation, 11, 543-547.

Williams, P., Burgess, N., \& Rahbek, C. (2000). Flagship species, ecological complementary and conserving the diversity of mammals and birds in sub-Saharan Africa. Animal Conservation, 3, 249-260.

Wunder, S. (2000). Ecotourism and economic incentives-an empirical approach. Ecological Economics, 32, 465-479.

Yu, D. W., Hendrickson, T., \& Castillo, A. (1997). Ecotourism and conservation in Amazonian Perú: short-term and long-term challenges. Environmental Conservation, 24, 130-138. 


\section{Figure captions}

Figure 1. Study area, showing the three lodges where the research was conducted and the different Natural Protected Areas of the region $(\mathrm{BZ}=$ Buffer Zone, TNR= Tambopata National Reserve, BSPN= Bahuaja-Sonene National Park). The reference map shows the position of the study area in Peru and South America.

Figure 2. Results of the hierarchical cluster analysis, showing the three different tourist typologies.

Figure 3. Main characteristics of the three tourist typologies identified.

Figure 4. Percentage of tourist types in the three lodges. 

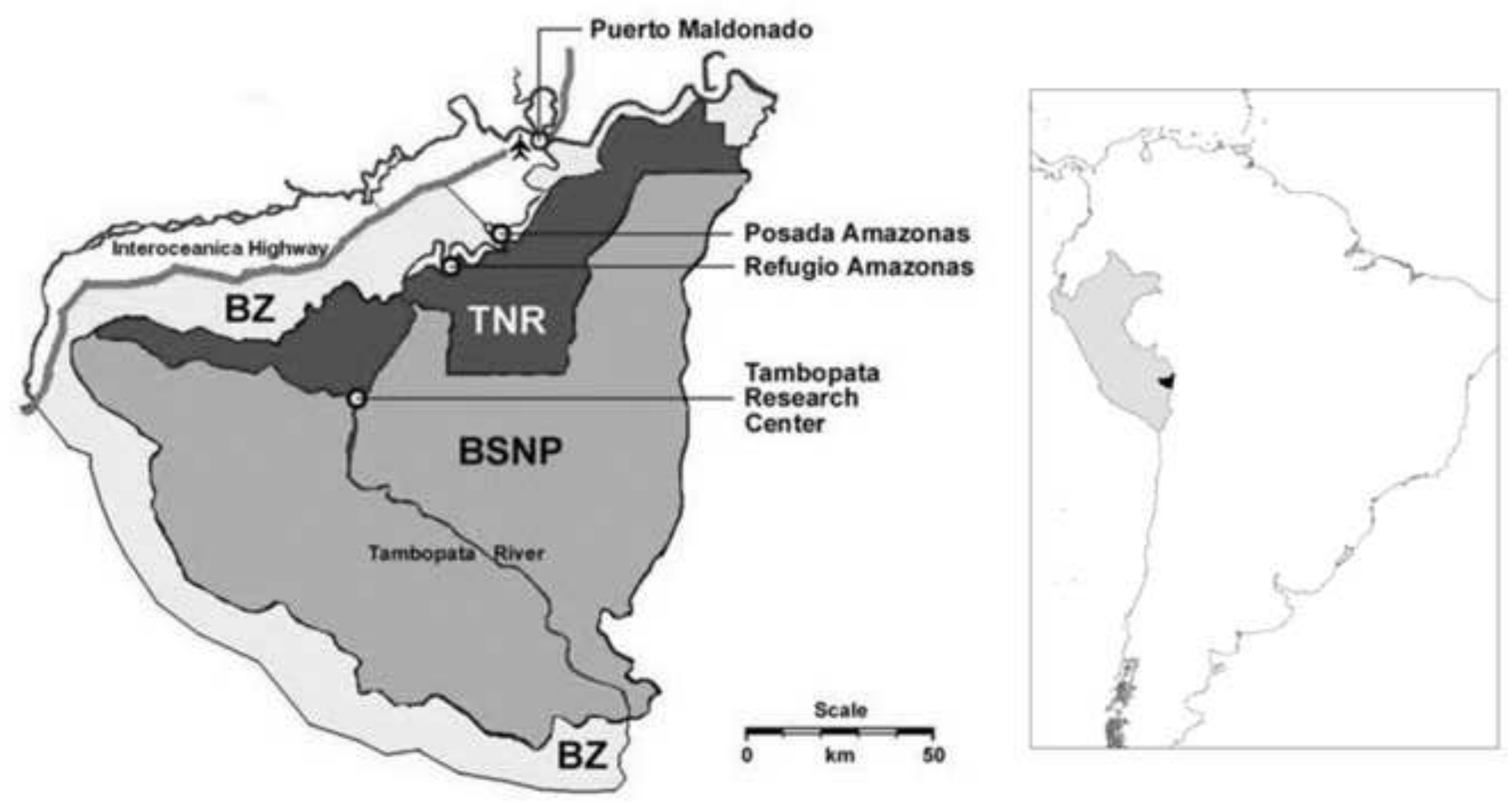
Click here to download high resolution image

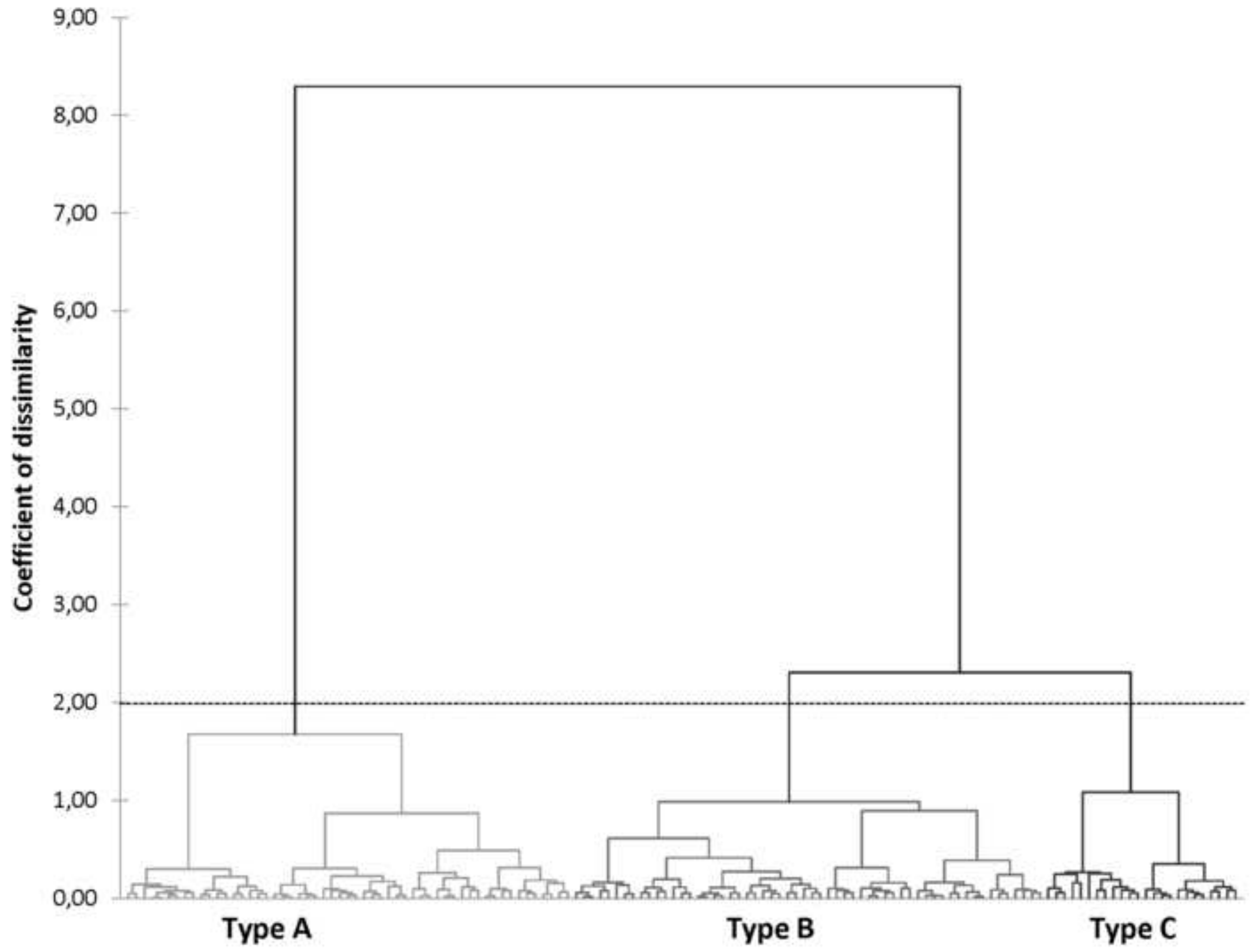



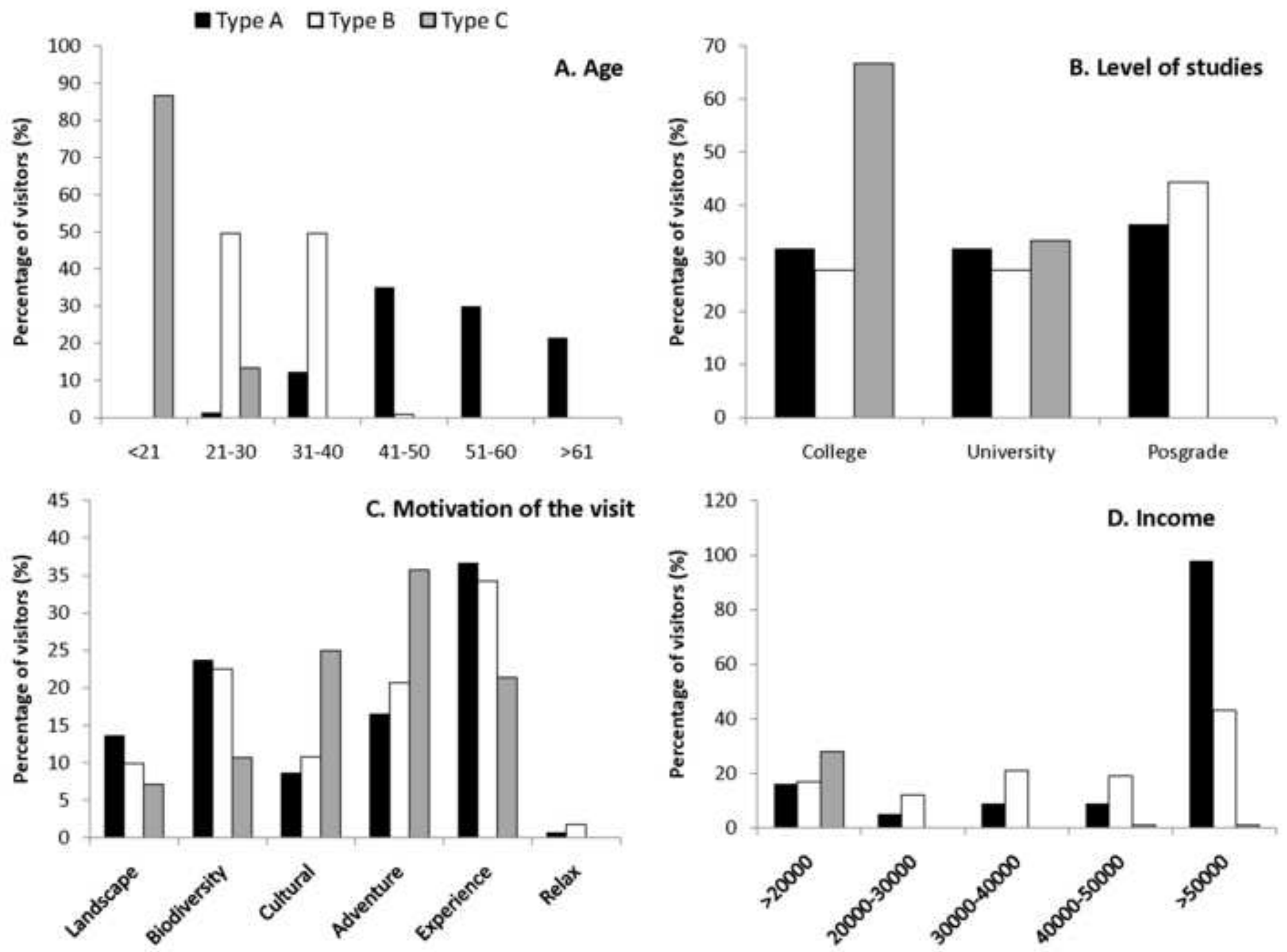
Click here to download high resolution image

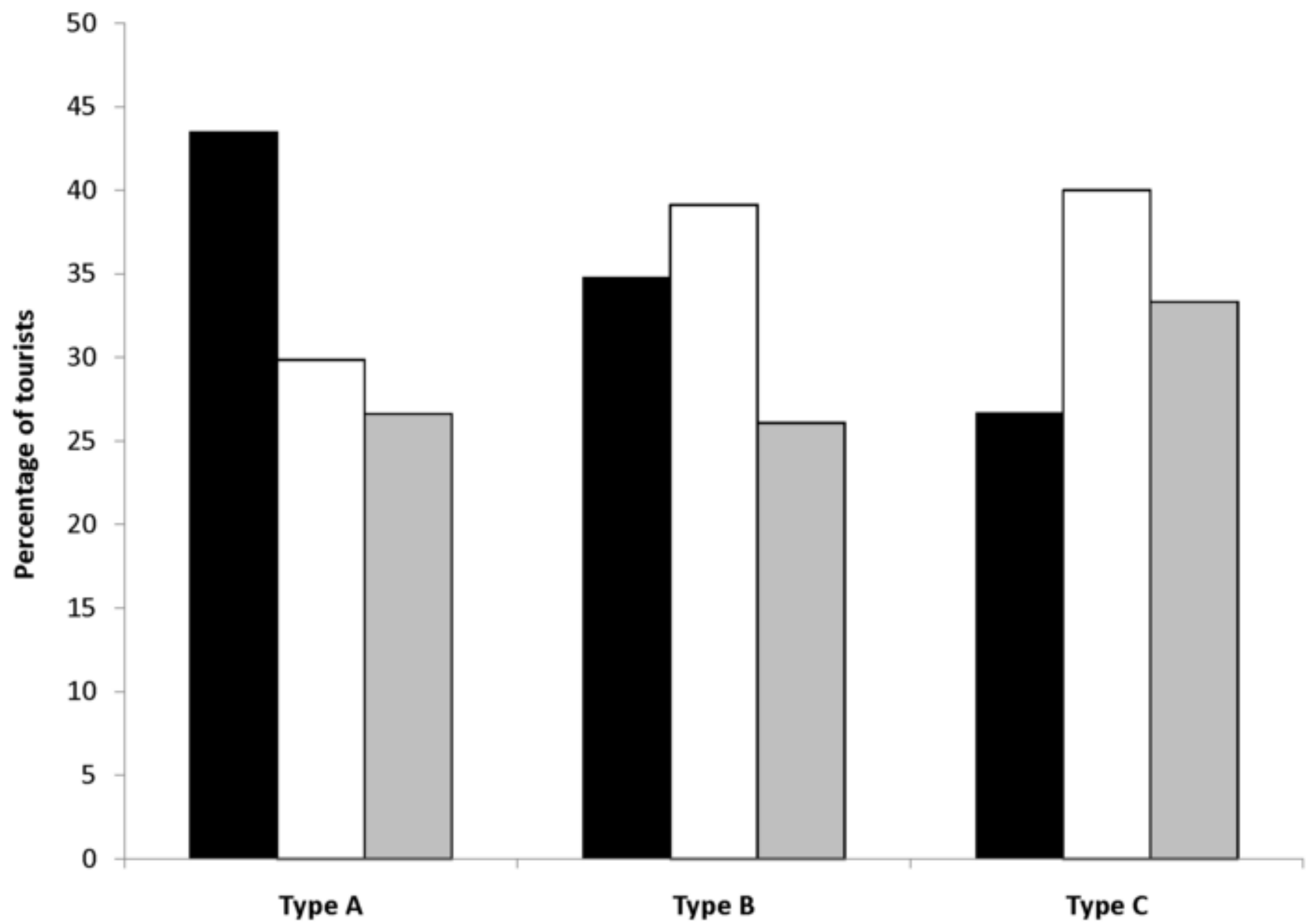

- Posada Amazonas $\quad \square$ Refugio Amazonas $\quad \square$ Tambopata Research Center 
Table 1

Summary of the variables used in the analysis, their main attributes, and the data source.

\begin{tabular}{|c|c|c|c|c|}
\hline Variables & & Type & Attributes & Data sources \\
\hline Dependent & Overall satisfaction & Ordinal & Satisfaction level between 1-7 & Tourists' questionnaires \\
\hline \multirow[t]{17}{*}{ Independent } & \multicolumn{4}{|l|}{ Socio-economic aspects } \\
\hline & Nationality & Categorical & $\begin{array}{l}\text { Categories: North America (USA and Canada), } \\
\text { Europe, Latin America, Asia and Oceania. }\end{array}$ & Tourists' questionnaires \\
\hline & Profession & Categorical & $\begin{array}{l}\text { Categories: Health sector, Education s., Legal s., } \\
\text { Economy s., Retired, Housewife, Sciences, } \\
\text { Engineering, Technical, Others }\end{array}$ & Tourists’ questionnaires \\
\hline & Age & Quantitative & Years & Tourists' questionnaires \\
\hline & Education level & Categorical & School (1), University (2), Postgraduate (3). & Tourists' questionnaires \\
\hline & Income & Ordinal & $\begin{array}{l}\text { In US\$: }<20000(1), 20000-30000(2), 30000-40 \\
000(3), 40000-50000(4),>50000(5)\end{array}$ & Tourists' questionnaires \\
\hline & \multicolumn{4}{|l|}{$\begin{array}{l}\text { Environmental and visit } \\
\text { attitudes }\end{array}$} \\
\hline & $\begin{array}{l}\text { Belonging to an environmental } \\
\text { NGO }\end{array}$ & Dichotomous & Yes (1), No (0) & Tourists' questionnaires \\
\hline & $\begin{array}{l}\text { Previous visits to natural } \\
\text { protected areas }\end{array}$ & Dichotomous & Yes (1), No (0) & Tourists' questionnaires \\
\hline & $\begin{array}{l}\text { Previous visits to tropical } \\
\text { rainforests }\end{array}$ & Dichotomous & Yes (1), No (0) & Tourists' questionnaires \\
\hline & Major motivation of the visits & Ordinal & $\begin{array}{l}\text { In order of preference, with a maximal value of } 6 \\
\text { and a minimal value of } 1 \text { : landscape, biodiversity, } \\
\text { cultural, experience, adventure, relaxation }\end{array}$ & Tourists’ questionnaires \\
\hline & Number of companions & Ordinal & Alone $=1$, couple $=2$, family $=3$, friends or group $=4$ & Tourists' questionnaires \\
\hline & \multicolumn{4}{|l|}{ Lodge characteristics } \\
\hline & Lodge and logistic quality & Ordinal & Satisfaction level between 1-7 & Tourists' questionnaires \\
\hline & $\begin{array}{l}\text { Lodge managed by a native } \\
\text { community }\end{array}$ & Dichotomous & Yes (1), No (0) & Direct observation \\
\hline & \multicolumn{4}{|l|}{ Guide characteristics } \\
\hline & Guide's quality & Ordinal & $\begin{array}{l}\text { Calculated index based on the enterprise's } \\
\text { evaluation and ranking provided by the enterprise. }\end{array}$ & $\begin{array}{l}\text { Direct question to the } \\
\text { enterprise. }\end{array}$ \\
\hline
\end{tabular}




\begin{tabular}{|c|c|c|c|}
\hline Guide's origin & Dichotomous & Native and non-native guide; local or not. & $\begin{array}{l}\text { Information provided by the } \\
\text { enterprise. }\end{array}$ \\
\hline \multicolumn{4}{|l|}{ Activity characteristics } \\
\hline Group size & Quantitative & Number of persons conducting the activity & Direct observation \\
\hline Activity time length & Quantitative & $\begin{array}{l}\text { Grouped in the categories; less than two hours }=1 \text {, } \\
\text { between two and four }=2, \text { more than four hours }=3\end{array}$ & Direct observation \\
\hline Activity distance & Quantitative & $\begin{array}{l}\text { Distance in kilometres walked, grouped in: }<2 \mathrm{~km} \\
(1) \text {, between } 2 \text { and } 4 \mathrm{~km}(2),>4 \mathrm{~km}(3)\end{array}$ & Direct observation \\
\hline Weather conditions & Dichotomous & $\begin{array}{l}\text { Presence of a weather incident during the activity: } \\
\text { Yes (1), No (0) }\end{array}$ & Direct observation \\
\hline Activity types & Categorical & $\begin{array}{l}\text { Terrestrial, aquatic, cultural, nocturnal, collpa and } \\
\text { tower activity }\end{array}$ & Direct observation \\
\hline \multicolumn{4}{|l|}{ Ecological characteristics } \\
\hline Forest successional state & Categorical & $\begin{array}{l}\text { Pristine (1), Secondary (2), Agroforestal (3), } \\
\text { Pioneer (4). }\end{array}$ & Direct observation \\
\hline $\begin{array}{l}\text { Number of species observed } \\
\text { more than } 25 \text { maway }^{\text {a }}\end{array}$ & Quantitative & $\begin{array}{l}\text { Mammals, birds, herpetofauna and entomofauna } \\
\text { index. }\end{array}$ & Direct observation \\
\hline $\begin{array}{l}\text { Number of species observed } \\
\text { less than } 25 \mathrm{~m} \text { away }{ }^{\text {a }}\end{array}$ & Quantitative & $\begin{array}{l}\text { Mammals, birds, herpetofauna and entomofauna } \\
\text { index. }\end{array}$ & Direct observation \\
\hline $\begin{array}{l}\text { Number of charismatic species } \\
\text { observed }\end{array}$ & Quantitative & $\begin{array}{l}\text { Number of birds (psittacids and representative } \\
\text { birds), mammals (primates, cats, peccaries and } \\
\text { giant river otters), herpetofauna, (large reptiles), } \\
\text { and entomofauna }\end{array}$ & Direct observation \\
\hline
\end{tabular}

a To analyse these variables, we developed an "index of observed fauna", separately for mammals, birds, herpetofauna and entomofauna. This index was calculated as the sum of the number of charismatic species observed and given the value of 1 for those observed closer than $25 \mathrm{~m}$ and 0.5 for those observed farther away. 
Table 2

Different variables influencing satisfaction level of the three tourist typologies.

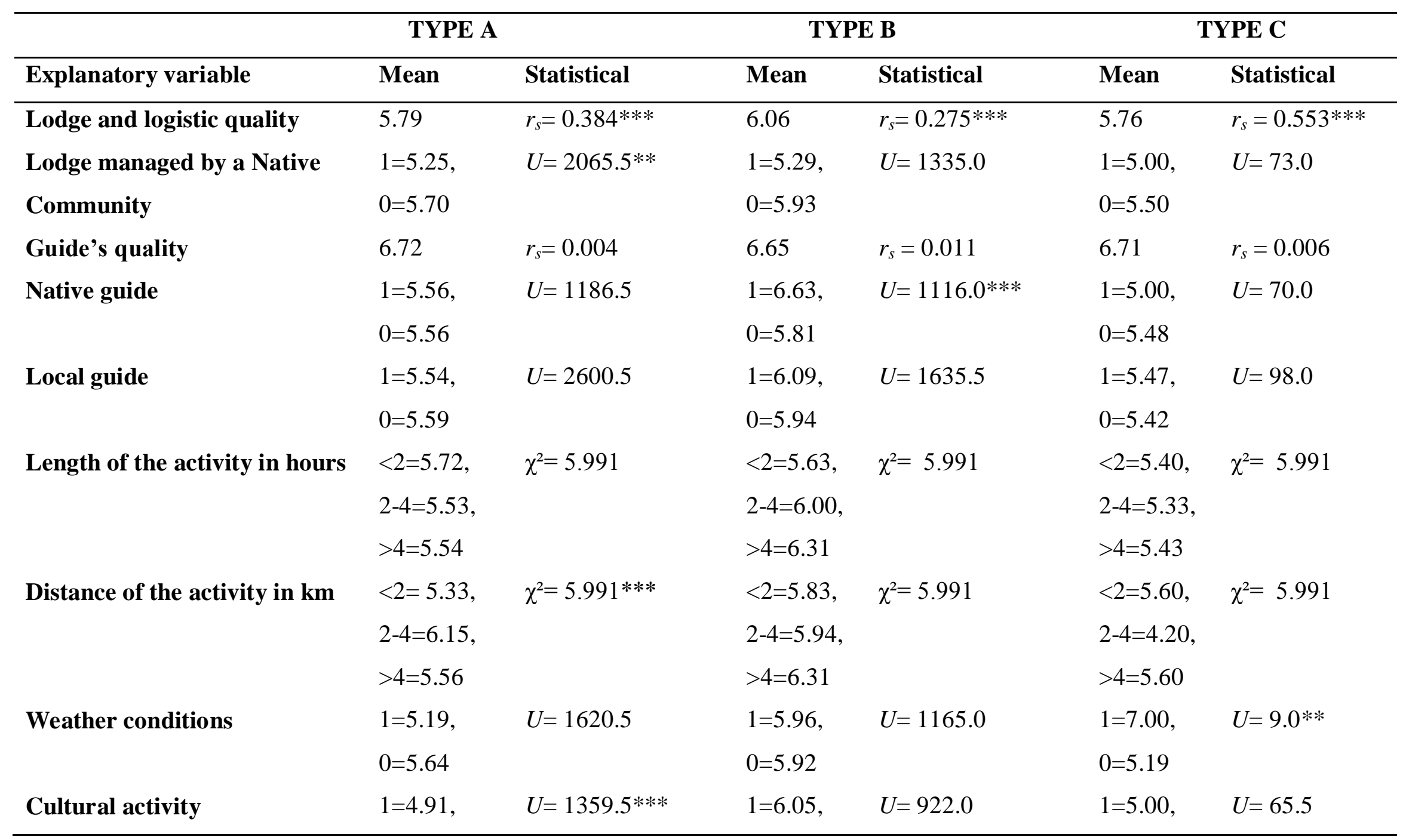




\begin{tabular}{|c|c|c|c|c|c|c|}
\hline & $0=5.76$ & & $0=5.90$ & & $0=5.46$ & \\
\hline Aquatic activity & $\begin{array}{l}1=5.56 \\
0=5.56\end{array}$ & $U=1499.0$ & $\begin{array}{l}1=6.31, \\
0=5.87\end{array}$ & $U=626.0$ & $\begin{array}{l}1=5.60 \\
0=5.32\end{array}$ & $U=60.5$ \\
\hline Tower activity & $\begin{array}{l}1=5.73 \\
0=5.54\end{array}$ & $U=868.5$ & $\begin{array}{l}1=5.89, \\
0=5.94\end{array}$ & $U=1226.0$ & $\begin{array}{l}1=6.00 \\
0=5.27\end{array}$ & $U=41.0$ \\
\hline Collpa activity & $\begin{array}{l}1=5.52 \\
0=5.57\end{array}$ & $U=2051.5$ & $\begin{array}{l}1=5.84 \\
0=5.95\end{array}$ & $U=1045.0$ & $\begin{array}{l}1=6.43, \\
0=5.04\end{array}$ & $U=39.0 * *$ \\
\hline Terrestrial activity & $\begin{array}{l}1=6.23, \\
0=5.38\end{array}$ & $U=1060.0 * * *$ & $\begin{array}{l}1=6.05 \\
0=5.90\end{array}$ & $U=730.0 * *$ & $\begin{array}{l}1=4.43, \\
0=5.65\end{array}$ & $U=116.0^{*}$ \\
\hline Nocturnal activity & $\begin{array}{l}1=5.71 \\
0=5.55\end{array}$ & $U=486.5$ & $\begin{array}{l}1=5.00 \\
0=6.01\end{array}$ & $U=664.0 * *$ & $\begin{array}{l}1=3.00 \\
0=5.45\end{array}$ & $U=27.0$ \\
\hline Secondary forest & $\begin{array}{l}1=5.47 \\
0=5.70\end{array}$ & $U=2242.5$ & $\begin{array}{l}1=5.85 \\
0=6.04\end{array}$ & $U=1288.0$ & $\begin{array}{l}1=5.18 \\
0=5.57\end{array}$ & $U=91.5$ \\
\hline Agroforestal forest & $\begin{array}{l}1=5.06 \\
0=5.63\end{array}$ & $U=1411.0 * *$ & $\begin{array}{l}1=5.88 \\
0=5.94\end{array}$ & $U=890.0$ & $\begin{array}{l}1=6.00 \\
0=5.27\end{array}$ & $U=40.0$ \\
\hline Pioneer forest & $\begin{array}{l}1=7.00 \\
0=5.53\end{array}$ & $U=58.5^{* *}$ & $\begin{array}{l}1=7.00 \\
0=5.90\end{array}$ & $U=54.0^{* *}$ & $\begin{array}{l}1=5.00 \\
0=5.45\end{array}$ & $U=19.0$ \\
\hline Mammal index & 0.11 & $r_{s}=0.001$ & 0.09 & $r_{s}=0.040 * *$ & 0.13 & $r_{s}=0.020$ \\
\hline Bird index & 0.24 & $r_{s}=0.009$ & 0.25 & $r_{s}=0.051 * *$ & 0.25 & $r_{s}=0.008$ \\
\hline
\end{tabular}




\begin{tabular}{lllllll}
\hline Herpetofauna index & 0.04 & $r_{s}=0.001$ & 0.04 & $r_{s}=0.002$ & 0.02 & $r_{s}=0.073$ \\
Entomofauna index & 0.01 & $r_{s}=0.001$ & 0.00 & $r_{s}=0.001$ & - \\
\hline
\end{tabular}

${ }^{*} \mathrm{p}<0.1, * * \mathrm{p}<0.05, * * * \mathrm{p}<0.0$ 
Table 3

Results of the Principal Component Analysis (PCA)

\begin{tabular}{|c|c|c|c|c|c|c|}
\hline \multirow[t]{2}{*}{ Variables } & \multicolumn{3}{|c|}{ Factor scores } & \multicolumn{3}{|c|}{ Squared cosine } \\
\hline & F1 & F2 & F3 & F1 & $\mathrm{F} 2$ & F3 \\
\hline Lodge and logistic quality & 0.310 & 0.179 & 0.929 & 0.094 & 0.031 & 0.850 \\
\hline $\begin{array}{l}\text { Lodge managed by a native } \\
\text { community }\end{array}$ & -0.183 & -0.262 & 0.005 & 0.141 & 0.289 & 0.000 \\
\hline Guide's quality & -0.545 & 0.816 & -0.001 & 0.282 & 0.631 & 0.000 \\
\hline Native guide & -0.094 & 0.037 & 0.014 & 0.070 & 0.011 & 0.002 \\
\hline Local guide & 0.010 & -0.126 & -0.010 & 0.000 & 0.064 & 0.000 \\
\hline Group size & -0.650 & -0.344 & 0.308 & 0.426 & 0.120 & 0.096 \\
\hline Activity time length & -0.247 & 0.100 & -0.007 & 0.415 & 0.068 & 0.000 \\
\hline Activity distance & 0.854 & 0.100 & -0.065 & 0.736 & 0.010 & 0.004 \\
\hline Weather conditions & 0.018 & -0.049 & 0.002 & 0.002 & 0.015 & 0.000 \\
\hline Cultural activity & -0.200 & -0.006 & 0.008 & 0.232 & 0.000 & 0.000 \\
\hline Aquatic activity & 0.265 & -0.095 & -0.004 & 0.500 & 0.064 & 0.000 \\
\hline Tower activity & -0.054 & -0.107 & 0.007 & 0.021 & 0.083 & 0.000 \\
\hline Collpa activity & -0.072 & -0.066 & 0.023 & 0.032 & 0.027 & 0.003 \\
\hline Terrestrial activity & 0.071 & 0.249 & -0.023 & 0.030 & 0.367 & 0.003 \\
\hline Nocturnal activity & -0.010 & 0.024 & -0.012 & 0.004 & 0.021 & 0.005 \\
\hline Forest succession & -0.191 & -0.318 & 0.136 & 0.074 & 0.204 & 0.037 \\
\hline Mammal index & 0.077 & 0.023 & -0.014 & 0.195 & 0.018 & 0.006 \\
\hline Bird index & 0.089 & -0.048 & 0.011 & 0.158 & 0.045 & 0.003 \\
\hline Herpetofauna index & 0.005 & 0.013 & 0.002 & 0.003 & 0.017 & 0.000 \\
\hline Eigenvalue & 1.822 & 1.116 & 0.984 & & & \\
\hline$\%$ variance explained & 28.590 & 17.509 & 15.431 & & & \\
\hline $\begin{array}{l}\text { Accumulated } \% \text { variance } \\
\text { explained }\end{array}$ & 28.590 & 46.099 & 61.530 & & & \\
\hline
\end{tabular}




\section{Table 4}

Multivariate regression model for tourists' overall satisfaction

\begin{tabular}{lrrrr}
\hline Variable & Coefficient & Standard deviation & T ratio & $\boldsymbol{p}$-value \\
\hline Constant & -0.099 & 0.133 & -0.746 & 0.456 \\
F1 & 0.155 & 0.032 & 4.830 & $<0.001$ \\
F2 & 0.137 & 0.041 & 3.356 & 0.001 \\
F3 & 0.660 & 0.044 & 15.098 & $<0.001$ \\
Type-A & 0.075 & 0.146 & 0.514 & 0.608 \\
Type-B & 0.278 & 0.150 & 1.854 & 0.065 \\
\hline$N$ & 320 & & & \\
$R^{2}$ & 0.509 & & & \\
Adjusted $R^{2}$ & 0.500 & & & \\
$F$ & 55.586 & & & \\
$p$-value & $<0.001$ & & & \\
\hline
\end{tabular}


Appendix 1. Questionnaire administered to individual ecotourists after the tour.

1. Nationality

2. Occupation / Profession

3. Higher education ( ) University ( ) Postgraduate ( )

4. Annual income US\$ < 20000 ( ), 20000-30000 ( ), 30000-40000 ( ), 4000050000 ( ), >50000 ( ).

5. Do you belong to any conservation organisation such as WWF, CI, ABC, etc? Yes ( ) No ( ).

6. Did you travel Alone ( ), With a partner ( ), Number of relatives___ ( ), Size of group (how many people?)

7. Have you previously visited a protected area? Yes ( ) No ( )

8. Have you previously visited a tropical forest? Yes ( ) No ( ) How many times?

9. What were the main reasons for your visit? Please give reasons in order with number 1 being the most important reason and 5 the least important.

Landscape ( ), Biodiversity ( ), Cultural ( ), Adventure ( ), Experience ( ), Relaxation ( ).

10. On a scale of 1 to 7 , with 7 being the maximum value, how satisfied were you with the logistics and accommodation during your trip? 1 ( ) 2 ( ) 3 ( ) 4 ( ) 5 ( ) $6($ ( ) 7 ( ).

11. On a scale of 1 to 7 , with 7 being the maximum value, how satisfied were you with the route/path that was just taken? 1( ) 2( ) 3( ) 4( ) 5( ) 6 ( ) 7() . 